\title{
11 \\ BRANDING THEORY \\ CONTRIBUTIONS TO CORPORATE REAL ESTATE MANAGEMENT
}

\author{
Rianne Appel-Meulenbroek ${ }^{\star}$ and Abdul Jalil Omar
}

\section{Background}

A brand is one way of identifying a product or a service. Doyle (1992, p. 319) suggested that "a successful brand is a name, symbol, design, or some combination, which identifies the "product or service' of a particular organization as having sustainable differential advantage". A richer brand definition, however, is presented by Macrae et al. (1995), who suggested that a brand represents a unique combination of characteristics and added values, both functional and nonfunctional, which have taken a relevant meaning linked to the brand. A brand thus "can be seen as a cluster of physical, functional and socio-psychological attributes, beliefs and values associated with a certain product or service" (Appel-Meulenbroek et al., 2010). Clearly, it takes more than physical images to develop and communicate a brand to all relevant stakeholders of an organisation.

\subsection{Branding origins}

Branding originates from the marketing field and quickly after that was enriched with many theories from the psychology field. It is suggested that the term "brand' entered the marketing field in 1922 (Stern, 2006), but according to Bastos and Levy (2012), there are already some studies stemming from a few years before that. Nonetheless, it did not really start to gain interest until the 1950s, and most research even dates from the current century (Roper \& Parker, 2006). Today, social sciences and humanities disciplines also study branding, arguing that branding efforts shape consumer desires and actions (Holt, 2002). There is also a lot of branding research in the tourism field, focused on city marketing and other forms of place branding (e.g. Kavaratzis, 2004). Additionally, the field of human resources (HR) is applying marketing theories to increase employer branding insights (e.g. App et al., 2012).

Roper and Parker (2006) distinguished four time-periods of branding theory development, which all have their own focus. First, the price was the main focus of branding theory (1979-1984), but later also the name (1987-1992) and the service (1993-1999) were included,

^Corresponding author: h.a.j.a.appel@tue.nl 
followed by viewing the brand as a company asset (2001-2005). They labelled these four stages of branding as identification, differentiation, personification, and asset. Identification of a brand takes place when consumers associate a product or service with its producer or the owner. This origin of product branding emphasises uniqueness, to ensure that the consumer recognises the product. But the need for a brand increased especially during the industrial revolution, when improvement in production processes allowed for mass production, economies of scale and consistent quality (Low \& Fullerton, 1994). The increased competition in the market demanded differentiation from others with similar products. As of then, consumers were encouraged to identify a product by name through mass communication, to strengthen the landing of products in the mind of customers for repeated purchasing from the same company. Distinctive brand differentiation among competing brands in the market can be achieved through innovation, which helps to maintain a dominant position for a longer period. Differentiation generally took place functionally or rationally (through size, package, quality, price and so on). From the 1990s, services were starting to be considered part of the brand to increase so-called personification. This moves a brand from a thing into a product with meaning to it, in order to emotionally attach consumers to it (Roper \& Parker, 2006). For example, a product endorsed by a celebrity will add charisma to it, and consumers prefer a product, a store or a service that aligns with their own desired personality. The 'meaning' is defined through the characteristics of the brand and is constructed by customers when associating with the brand (Aaker \& Fournier, 1995). After all, a company may try to create a powerful brand identity, but in the end the consumers create the brand meaning. With the turn of the century, the value of a brand also started to be seen as an asset for the company, turning a brand into just as important a value as other company assets.

\subsection{Branding dimensions}

Nowadays, branding theory distinguishes many different dimensions, both in relevant terms/ concepts and in who is involved in communicating the brand and who is targeted by it. Regarding the latter, product branding is the base to sell products to customers, but it is not enough for companies to focus on creating reputation solely through products' quality (due to the standardisation and homogeneity of production processes nowadays). Therefore, so-called corporate branding aims at disseminating values and emotions symbolised by the company. It regards the corporate reputation as perceived by several different relevant stakeholders (Orozco-Toro \& Ferre-Pavia, 2019). When the war on talent started, another stakeholder was added through so-called employer branding, that aimed this dissemination of company values not at customers, but at potential future employees. As Edwards (2010, p. 6) put it: "Whereas product branding considers how a product is represented to customers and corporate branding considers how an organisation is represented to a variety of external audiences, employer branding considers current and potential employees as branding targets". Successful organisations thus need to have a holistic, consistent and integrated approach to corporate branding. All organisational members should be contributors to the creation of the corporate brand, to achieve genuine coherence between the promise the brand makes and the performance the corporation delivers (Hatch \& Schultz, 2003). The corporate brand then moves beyond the visual part of the brand, such as the logo and building, into multiple channels of communication, such as staff behaviour (Balmer \& Gray, 2003). To do so, organisations must create synergy between the brand and the organisational culture (Hatch \& Schultz, 2003), which is deeply embedded in organisational behaviour. Kaplan and Norton (2001) have stressed a relationship between employee behaviour and customer impression and retention. They state as an example for the retail sector that a compelling place to work leads to a compelling place to shop. The reality that they are trying to 
deliver is that employee-centred services might be just as important as the clichéd statement to the external customers. But challenging the norm and creating synergy between the brand and the organisational culture is not easy (De Chernatony \& Cottam, 2006).

Customer services (either as the main source of income of a company or related to their physical products) also add to the holistic experience of the brand. In order for a service to support a strong brand, the consumer must be aware of notable differences between the provider's offerings. Therefore, some scholars emphasise the creation of a strategic function internally, leaving the fixation on input and outcomes/sales (e.g. Gyrd-Jones et al., 2013; Kapferer, 2012; Balmer, 2010). Only then, organisations are integrating functional silos towards a dynamic corporate branding that supports stakeholder buy-in and branding outcomes (Vallaster \& Lindgreen, 2011).

A second 'set' of dimensions regards the concepts/terms related to branding. Branding refers to the communication of what the organisation is, what it does and how it does it: which becomes visual through the so-called corporate identity (Markwick \& Fill, 1997). Another concept that is often used in branding literature is 'image'. As Nandan (2005, p. 264) explains, "identity originates from the company, ie a company is responsible for creating a differentiated product with unique features. Brand image refers to consumer perceptions and encompasses a set of beliefs that consumers have about the brand". Or. as Sääksjärvi and Samiee (2011, p. 170) put it, "brand identity represents how firms aspire to be perceived, whereas brand image refers to how they are perceived". Both concepts are essential ingredients of strong brands (Nandan, 2005). Melewar and Karaosmanoglu (2006) claim that not only corporate culture determines corporate communication and thus corporate identity, although it is the starting point in their model. Additionally, the influence of corporate culture on corporate strategy and corporate behaviour is relevant, as all three aspects in turn influence corporate communication efforts to express the corporate identity as well. Another indirect line in their model flows from corporate strategy through corporate structure to corporate design and then into corporate communication and identity as well. This indirect line might be the most obvious way of branding and its oldest form, as it is the most visible and explicit form of communication; but as discussed earlier, behaviour is just as relevant.

What Melewar and Karosmanoglu's model overlooks is that corporate design, especially the physical workplace design, also influences employee behaviour and how well employees can perform their work (Appel-Meulenbroek et al., 2010). This is discussed in greater detail in the next section on the application of branding theory to workplaces, distinguishing the three different types of stakeholders that came forward to benefit from branding efforts: consumers of the companies' products/services, potential future employees, and current employees.

\section{Applicability to workplace studies}

Design aspects of the work environment are considered relevant for communicating corporate identity. So, corporate real estate (CRE) and facility management can help or hinder the communication of the corporate brand. However, so far branding models mainly mention aesthetical design factors of the workplace, such as the building's architecture and office layout as a direct influence on corporate communication to consumers passing by or visiting the building. They disregard the potentially strong relationship between the physical working environment and employee behaviour, as an indirect influence of CRE on corporate communication. Additionally, more and more organisations have started using their physical office designs for employer branding (e.g. the circular building of Google with slides as an alternative to stairs to emphasise playfulness). Besides supporting the organisation in communicating their corporate identity to 
customers and employees (being internal customers), branding theory could additionally be relevant for CREM internal branding, to show its added strategic value for the organisation more clearly. So, this section explains these three ways how a branding theory could be applied to corporate real estate management:

1 Direct and indirect physical communication of corporate identity to consumers.

2 Employer branding.

3 CREM internal service branding.

\subsection{Direct and indirect physical communication of corporate identity to consumers}

Lindholm and Leväinen (2006) identified several ways in which CREM might add strategic value to promoting company marketing and sales, by their help in communicating corporate identity towards an improved corporate image. They mentioned that CREM should:

- Select locations that capture customers,

- Provide space that attracts customers,

- Make a symbolic statement through design and location,

- Create a workplace that supports the corporate brand,

- Provide the environment that supports the sale.

Interviews of CRE managers indicated that their most commonly aspired brand images are values like sustainability, reliability, transparency, innovation and being people-oriented (Khanna et al. (2013). However, these should also match the values of the organisations as a whole.

There are only a few concrete studies on the direct and indirect effect of workplace aspects on a company's branding success and customers' perceptions of their image. Regarding potential direct effects of the workplace, Bitner (1992) explored the impact of ambiance conditions (like temperature, sound, light and smell), space and function, and signs, symbols and artefacts on customers. Hatch and Cunliffe (2006) and Strati (1999) explored the relationship between CRE and images of companies more specifically, distinguishing location, layout and style as important factors. Appel-Meulenbroek et al. (2010) asked workplace managers of different (service) companies how they thought that a list of physical workplace aspects would help with corporate branding. All aspects that they tested for a direct or indirect influence were considered helpful: location typology and reputation, landscaping, façade, recognisability, quality of finishing, the main entrance, architectural style, visibility, floor plan, accessibility and indoor environmental quality (IEQ), facilities in the neighbourhood, accessibility by car, bicycle or public transport and restaurant facilities. However, the most important tools for branding in a direct way were considered to be the accessibility and typology of the location, the quality of the finishing and recognisability of the building, and the main entrance. Organisations convey a certain message through their building lobby, main entrance, facilities as well as signage to their customers and employees. To an extent, the terms brand and landscaping have even integrated to the term 'brandscaping' (coined by Sherry, 1987).

Regarding indirect effects, satisfied employees are able to bring more value to the company and are willing to go the extra mile to satisfy their external customers (De Chernatony \& Cottam, 2006; Punjaisri \& Wilson, 2007). Loyal and satisfied external customers are a result of quality employees who received internal service quality from company business functions like CREM. It is an internal quality chain reaction from internal customers to the external 
customers to work synergistically. To satisfy employees, not only IEQ, furniture and equipment, enough diversity of functional spaces, and supportive facility services are important, but also softer aspects such as décor and privacy (van der Voordt et al., 2016).

\subsection{Employer branding}

As Backhaus and Tikoo (2004, p. 502) argued, employer branding "suggests differentiation of a firm's characteristics as an employer from those of its competitors, the employment brand highlights the unique aspects of the firm's employment offerings or environment". More recently, Backhaus (2016) pointed out that despite hundreds of published articles on this topic, many key aspects still need further investigation, and there is no agreement on which attributes are most important. Nonetheless, with the scarcity of talent in many knowledge-based sectors, employer branding is also increasingly including the office where a person gets to work. Organisations create trendy, modern offices to convince young talent that they will provide them with an attractive workplace experience if they become their employee. So far, there is little evidence whether the physical work environment actually makes the difference in choosing between jobs. A study by Themans et al. (2020) appears to be the only one that specifically included real estate in their study on employer branding. When asking knowledge workers to allocate points to aspects influencing an organisation's attractiveness as employer, real estate was the second lowest rated factor, only above organisational image and below rewards, social climate, development opportunities and working hours. However, as they argued in their study, the differences were very small, so real estate is clearly also a relevant aspect. Regarding the studied aspects within the real estate category, they identified location as the most important one, followed by the individual workspace, services and facilities and, last, the building itself. Especially the accessibility and the geographic position of the location scored high on creating an attractive employer.

\subsection{CREM internal service branding}

As visible in Chapter 12 on the Value Adding Management model, CREM can add value to the core business of a client organisation in many ways. Nonetheless, there remains a strong focus of CREM and general management in practice on cost efficiency of providing accommodation. Such a focus on unit costs and building condition, rather than on overall costs and business outcomes affected by the workplace design, is the reason that CREM has a hard time capturing strategic attention (Price et al., 2009). But there is increased attention for showing the full value and contribution of CREM (Heywood \& Kenley, 2008). Perhaps better internal branding of the CREM/FM department could help with that. As Omar and Heywood (2014, p. 74) mentioned, "CREM needs to better frame itself in terms of supporting business as that is what their customers saw as CREM's core competence". CREM internal service branding is a process of building a service brand from inside out through tangible and intangible assets, and of a company's mission and their commitment to satisfy their most important customer, which is the employees. For employees, their workplace is more than just a business resource, as it also reflects their psychological needs, such as territoriality, privacy, autonomy and social interaction with other people (see Budie et al., 2019). Besides, physical workplace conditions include emotional and physiological aspects for individuals through attachment, familiarity and identity (Inalhan, 2009). Ignoring the emotional effects can damage human well-being from a socio-psychological point of view but also might influence their behaviour towards customers. 
From the three branding applications discussed in this chapter, internal service branding might be the biggest branding challenge of CREM for several reasons:

1 Optimal workplace support is complex, as functional, physical and psychological aspects could all play a part. A structured literature review by Appel-Meulenbroek et al. (2018) identified 134 studies, from which they extracted 10 employee outcomes that have been proven to be affected by the physical work environment, plus 8 categories of workplace 'design' variables that could be used to influence these outcomes. Therefore, there are many product and service qualities that could be branded internally towards employees and general management.

2 Different internal stakeholders prefer different settings for an optimal workplace experience. The major question top management would like to have answered is probably how the workplace design and other physical elements are able to create value for productivity and competitiveness. Employees, on the other hand, might care more about their wellbeing, privacy and support of activities. Plus, there is no one solution for every employee because so many individual differences in preferences exist (Budie et al., 2019). It can thus even be considered a wicked problem, because as Kreuter et al. (2004) describe, wicked problems are difficult to pin down and influenced by a constellation of complex social and political factors that change over time. Workplace management is also subject to such a constellation (see also Chapter 4 on the St. Gallen Management Model and Chapter 7 on Strategy-as-Practice).

3 Justifying tangible real estate contributions to employee productivity and behaviour is quite challenging; the latter because it is hard to isolate the effects of physical aspects from other factors influencing the employee at the same time. For example, empirical testing of the workplace impact on personal productivity and organisational value is still scarce (De Paoli et al., 2013).

4 The strategic importance of internal service branding relies heavily on the service provider's action and communication (Kang, 2016). As an internal service function to a business, CREM needs to communicate its expertise and performance in fulfilling companies' requirements to improve employees' and management's trust. However, this is always a collective contribution with other business functions such as HR, IT and finance and thus asks for working in harmony with such departments. And generally external service providers are hired to fulfil part of the CREM service delivery as well, so they are also part of communicating the CREM service.

What is important is how CREM plays its role in the brand-building process to translate the external brand values to the internal organisation values or vice versa. Omar and Heywood (2014) highlighted that workplace acceptance among employees increases when CREM is perceived as trusted and a reliable contact point to provide them with the necessary tangible and intangible conditions to perform at their best. Employees also need to have a better understanding of the meaning of the workplace in order to adapt smoothly to a new situation (Inalhan, 2009). The internal market of employees requires tailored services that fit with what the organisation wants to communicate to the outside. Thus, satisfying internal customers seems as equally important as satisfying external customers in providing quality products or services to the market.

As businesses strive to improve their competitive position in a crowded marketplace, strategic use of all resources, including CREM, into marketing strategies is necessary to succeed. Even though CREM does not directly engage with external customers, they are thus also a stakeholder in developing a strong and sustainable corporate brand for companies. 


\section{Methodology/research approach}

Branding research has benefited from a full range of quantitative and qualitative methods, even including neural techniques and ethnographic methods (Keller, 2020). However, literature reviews show that while business-to-business branding (Keränen et al., 2012) and nation branding (Hao et al., 2019) studies mostly use surveys, place branding studies are mostly conceptual, qualitative studies (Acharya \& Rahman, 2016). Keränen et al. (2012) also emphasise a lack of longitudinal research and focus on single industries. Only a few studies are focused on CREM and branding. Many of these studies are using either single or multiple case study approaches, sometimes with a combination of several research methods, including quantitative and/or qualitative data collection (e.g. De Paoli et al., 2013; Gyrd-Jones et al., 2013; Omar \& Heywood, 2014). The strength of multiple cases obviously is the larger sample size, which is beneficial to understanding the triangulation of practices from several industries or different parties within the organisation, such as CREM managers, business units, other business functions and top management. For the direct and indirect physical branding, studies mainly asked CRE managers how they approach this and what they find most important/relevant. This helps to understand the association between the physical elements and corporate identity, such as the relationship of corporate branding to internationalisation (Foroudi et al., 2019; Khanna et al., 2013). However, it does not provide proof for the impact of CREM branding on the corporate communication of the brand. Future studies should thus further analyse characteristics or phenomena relevant for external CREM branding and their impact on stakeholders. A qualitative approach can be in the form of focus groups, observation and in-depth interviews with company clients. Quantitative approaches should include more large-scale survey studies that can identify how the effort of branding through CRE is perceived and whether it is thus successful. Such data could be obtained from company customers, those people living in the neighbourhood of the company's buildings, and/or passers-by (in the case of heavy trafficked locations). Similarly, more largescale studies like Themans et al. (2020) could identify in greater detail how CREM can support employer branding the best way.

Regarding internal CREM branding, generally, studies are also based on case studies to provide insights in correlation of physical changes with employee performance and other employee and/or organisational outcomes (Omar \& Heywood, 2014; Palm, 2016). The intention of such studies is to create a new way of thinking about the physical changes in the workspace and its meaning to employees or other stakeholders (Skogland \& Hansen, 2017). For example, Palm (2016) used the evaluation from CREM's customers (top-level management) from 24 companies in Sweden. But a broader customer evaluation (e.g. employees, neighbours, clients) could provide CREM with different perspectives on strategies for improving their level of quality in CREM services. Recent large-scale literature reviews (e.g. Appel-Meulenbroek et al., 2018; Engelen et al., 2019) have shown that the added strategic value of CREM to the business is a complex set of dependent and independent variables. More of these structured overview studies could together form the input towards a business case for CRE interventions, which CREM could use for internal branding of their preferably strategic position.

\section{Limitations}

There are no real limitations in applying branding theory and research methods to workplace research. As described before, the theoretical concepts in the Melewar and Karaosmanoglu's (2006) model can be successfully applied to CREM research (and already have been, albeit a few times only). Also, many methodologies used to study branding are no different from 
methodologies generally used in workplace research, such as surveys, interviews, observations, experiments and focus groups. However, some additional marketing research methods might be harder to apply to workplace research because the necessary data is not available in the public domain. For example, product-based companies can do competitive analyses with direct competitors on market share and brand familiarity, and they can study consumer buying behaviour by using data from national/regional statistics or online sales platforms, or even observe consumer behaviour in shopping areas. On the contrary, CREM data of competitors in the same industry sector are not available and hard to obtain; a lot is invisible unless the buildings can be visited, and FM systems could be accessed. Also, for direct and indirect physical branding, neighbours and passers-by might not be interested in collaborating in research on how they perceive a company's CRE appearance, as there is nothing to gain for them (opposed to being informed about retail products). Regarding internal CREM branding, there is still little benchmarking available, except for employees' workplace experience through the (paid) survey-based Leesman index (www.leesmanindex.com). As CREM departments do not share how well they are performing, this kind of research is thus also more difficult.

\section{Theory relevance to practice}

While CREM internal service branding and support of employer branding is relevant for all (larger) organisations, the relevance of direct physical communication by the CRE of the corporate identity to consumers probably depends on the business sector that a company is in. It seems more relevant for companies with frequent interactions with customers on site, such as banks and retailers. Nonetheless, it also matters if the CRE is located on a visible location, such as a city centre or busy highway location with many passers-by.

As there are few proven effects yet, CREM in practice should start applying branding theory through identifying a list of relevant internal and external stakeholders. Only by obtaining information from a representative delegation they can really identify how to improve their support of the corporate brand and their internal branding process. So far, evidence is obtained only from a few sectors or by non-representative samples of several sectors. So, these findings need to be tested in practice for the specific business type and sector that a CREM's client organisation represents. Understanding the key CRE factors that can influence the corporate brand of their specific organisation and their internal branding provides guidelines for designing a CREM strategy that supports both successfully. Both for external and internal branding efforts, towards consumers and towards current and potential employees, individual/group preferences need to be considered, which also depend on personal characteristics such as gender, age, personality and activity profile. Even internally, an organisation could have to deal with a variety of subcultures that also (need to) find expression in the corporate brand.

A successful corporate branding strategy is holistic, consistent and integrated and it requires not only the company's formal communication system but also many informal interactions a company has with its various stakeholders. Brand building involves a coordinated, interdisciplinary effort which plays a large role in forming the image and reputation of the corporate brand. CREM in practice needs to show the role their discipline can play in the organisation, as this is often still largely overlooked. A lot could be learned from sectors where the communication of corporate identity to external consumers through CRE appearance has occupied a central place in these organisations' corporate marketing practice (e.g. retailers).

For internal service branding, the CREM departments of different organisations could exchange more knowledge and experiences to work more rapidly towards a clear business case of workplace interventions. As CRE interventions are generally not done frequently, it would 
take a long time for a single CREM department to gather all necessary insights for a successful internal branding strategy. The jointly acquired knowledge could then inform internal brand alignment, which should explicitly consider current and future demand for CREM from current and future portfolios. Heywood and Arkesteijn (2017) suggested the importance of a multidirectional alignment strategy that helps to evident CREM brand strategies in organisations. As a result, this multi-directionality would make them able to reach multiple stakeholders to provide comprehensive alignment directions (see also Chapter 9 on alignment theory). Successful support of corporate branding strategies through CRE management will require comprehensive feedback from management and lower organisational levels, to complete the loop in assessing progress and making adjustments when needed. Early development of a business strategy plan with objective measurements for real estate might provide CREM with a framework that could help them explainable their value to decision makers in their organisation. Then, CREM can move smoothly into the strategic planning process and live up to the potential to add strategic value to their organisation.

\section{Further reading}

Appel-Meulenbroek, R., Havermans, D., Janssen, I., \& Van Kempen, A. (2010). Corporate branding: An exploration of the influence of CRE. Journal of Corporate Real Estate, 12(1), 47-59. doi:10.1108/146300 11011025915

Omar, A. J., \& Heywood, C. A. (2014). Defining a corporate real estate management's (CREM) brand. Journal of Corporate Real Estate, 16(1), 60-76. doi:10.1108/JCRE-10-2013-0031

Themans, S., Koppels, P. W., \& Jylhä, T. (2020). The Contribution of the Work Environment on Employee Attraction. In The Proceedings of the 19th EuroFM Research Symposium, EFMIC 2020, 3-4 June, Online Conference. www.dropbox.com/s/yp4irmmnanw7fl1/Proceedings_EuroFM_2020.pdf?dl=0

\section{References}

Aaker, J., \& Fournier, S. (1995). A brand as a character, a partner and a person: Three perspectives on the question of brand personality. Advances in Consumer Research, 22, 391-395. https://search.ebscohost. com/login.aspx?direct $=$ true\&AuthType $=$ sso\& $\mathrm{db}=\mathrm{edsbl \& AN}=\mathrm{EN} 030014110 \&$ site $=$ eds-live $\&$ scope $=$ site

Acharya, A., \& Rahman, Z. (2016). Place branding research: A thematic review and future research agenda. International Review on Public and Nonprofit Marketing, 13(3), 289-317. doi:10.1007/s12208-015-0150-7

App, S., Merk, J., \& Büttgen, M. (2012). Employer branding: Sustainable HRM as a competitive advantage in the market for high-quality employees. Management Revue, 23(3), 262-278. doi:10.1688/1861-9908_mrev_2012_03_App

Appel-Meulenbroek, R., Clippard, M., \& Pfnür, A. (2018). The effectiveness of physical office environments for employee outcomes: An interdisciplinary perspective of research efforts. Journal of Corporate Real Estate, 20(1), 56-80. doi:10.1108/JCRE-04-2017-0012

Appel-Meulenbroek, R., Havermans, D., Janssen, I., \& Van Kempen, A. (2010). Corporate branding: An exploration of the influence of CRE. Journal of Corporate Real Estate, 12(1), 47-59. doi:10.1108/146300 11011025915

Backhaus, K. (2016). Employer branding revisited. Organization Management Journal, 13(4), 193-201. doi: 10.1080/15416518.2016.1245128

Backhaus, K., \& Tikoo, S. (2004). Conceptualizing and researching employer branding. Career Development International, 9(5), 501-517. doi:10.1108/13620430410550754

Balmer, J. M. T. (2010). Explicating corporate brands and their management: Reflections and directions from 1995. Journal of Brand Management, 18(3), 180-196. doi:10.1057/bm.2010.46

Balmer, J. M. T., \& Gray, E. R. (2003). Corporate brands: What are they? What of them? European Journal of Marketing, 37(7/8), 972-997. doi:10.1108/03090560310477627

Bastos, W., \& Levy, S. J. (2012). A history of the concept of branding: Practice and theory. Journal of Historical Research in Marketing, 4(3), 347-368. doi:10.1108/17557501211252934

Bitner, M. (1992). Servicescapes: The impact of physical surroundings on customers and employees. Journal of Marketing, 56(2), 57-71. doi:10.1177/002224299205600205 
Budie, B., Appel-Meulenbroek, R., Kemperman, A., \& Weijs-Perrée, M. (2019). Employee satisfaction with the physical work environment: The importance of a need based approach. International Journal of Strategic Property Management, 23(1), 36-49. doi:10.3846/ijspm.2019.6372

De Chernatony, L., \& Cottam, S. (2006). Internal brand factors driving successful financial services brands. European Journal of Marketing, 40(5-6), 611-633. doi:10.1108/03090560610657868

De Paoli, D., Arge, K., \& Hunnes-Blakstad, S. (2013). Creating business value with open space flexible offices. Journal of Corporate Real Estate, 15(3/4), 181-193. doi:10.1108/JCRE-11-2012-0028

Doyle, P. (1992). Branding. In M. J. Baker(Ed.), The Marketing Book (2nd ed.). UK: Butterworth-Heinemann.

Edwards, M. R. (2010). An integrative review of employer branding and OB theory. Personnel Review, 39(1), 5-23. doi:10.1108/00483481011012809

Engelen, L., Chau, J., Young, S., Mackey, M., Jeyapalan, D., \& Bauman, A. (2019). Is activity-based working impacting health, work performance and perceptions? A systematic review. Building Research E Information, 47(4), 468-479. doi:10.1080/09613218.2018.1440958

Foroudi, M. M., Balmer, J. M. T., Chen, W., \& Foroudi, P. (2019). Relationship between corporate identity, place architecture and identification: An exploratory case study. Qualitative Market Research, 22(5), 638-668. doi:10.1108/QMR-03-2017-0076

Gyrd-Jones, R., Helm, C., \& Munk, J. (2013). Exploring the impact of silos in achieving brand orientation. Journal of Marketing Management, 29(9/10), 1056-1078. doi:10.1080/0267257X.2013.811283

Hao, A. W., Paul, J., Trott, S., Guo, C., \& Wu, H. H. (2019). Two decades of research on nation branding: A review and future research agenda. International Marketing Review, early cite. doi:10.1108/ IMR-01-2019-0028

Hatch, M. J., \& Cunliffe, A. L. (2006). Organization Theory. Oxford, UK: Oxford University Press.

Hatch, M. J., \& Schultz, M. (2003). Bringing the corporation into corporate branding. European Journal of Marketing, 37(7/8), 1041-1064. doi:10.1108/03090560310477654

Heywood, C., \& Arkesteijn, M. H. (2017). Alignment and theory in corporate real estate alignment models. International Journal of Strategic Property Management, 21(2), 144-158. doi:10.3846/1648715X. 2016.1255274

Heywood, C., \& Kenley, R. (2008). The sustainable competitive advantage model for corporate real estate. Journal of Corporate Real Estate, 10(2), 85-109. doi:10.1108/14630010810905606

Holt, D. B. (2002). Why do brands cause trouble? A dialectical theory of consumer culture and branding. Journal of Consumer Research, 29(1), 70-90. doi:10.1086/339922

Inalhan, G. (2009). The unrecognized link between employees and their workplace. Journal of Corporate Real Estate, 11(1), 17-37. doi:10.1108/14630010910940534

Kang, D. S. (2016). Turning inside out: Perceived internal branding in customer-firm relationship building. Journal of Services Marketing, 30(4), 462-475. doi:10.1108/JSM-07-2015-0229

Kapferer, J.-N. (2012). The New Strategic Brand Management: Creating and Sustaining Brand Equity Long Term (5th ed.). London: Kogan Page.

Kaplan, R., \& Norton, D. (2001). The Strategy-Focused Organization. Boston, MA: Harvard Business School Press.

Kavaratzis, M. (2004). From city marketing to city branding: Towards a theoretical framework for developing city brands. Place Branding, 1(1), 58-73. doi:10.1057/palgrave.pb.5990005

Keller, K. L. (2020). Consumer research insights on brands and branding: A JCR curation. Journal of Consumer Research, 46(5), 995-1001. doi:10.1093/jcr/ucz058

Keränen, J., Piirainen, K. A., \& Salminen, R. T. (2012). Systematic review on B2B branding: Research issues and avenues for future research. Journal of Product \& Brand Management, 21(6), 404-417. doi:10.1108/10610421211264892.

Khanna, C., van der Voordt, T., \& Koppels, P. (2013). Corporate real estate mirrors brand: A conceptual framework and practical applications. Journal of Corporate Real Estate, 15(3/4), 213-230. doi:10.1108/ JCRE-01-2013-0003

Kreuter, M. W., De Rosa, C., Howze, E. H., \& Baldwin, G. T. (2004). Understanding wicked problems: A key to advancing environmental health promotion. Health Education E Behavior, 31(4), 441-454. doi:10.1177/1090198104265597

Lindholm, A., \& Leväinen, K. I. (2006). A framework for identifying and measuring value added by corporate real estate. Journal of Corporate Real Estate, 8(1), 38-46. doi:10.1108/14630010610664796

Low, G. S., \& Fullerton, R. A. (1994). Brands, brand management, and the brand manager system: A criticalhistorical evaluation. Journal of Marketing Research, 31(2), 173-190. doi:10.2307/3152192 


\section{Branding theory contributions}

Macrae, C., Parkinson, S., \& Sheerman, J. (1995). Managing marketing's DNA: The role of branding. Irish Marketing Review, 8, 13-20. http://search.proquest.com.ezp.lib.unimelb.edu.au/docview/204574504? accountid $=12372$

Markwick, N., \& Fill, C. (1997). Towards a framework for managing corporate identity. European Journal of Marketing, 31(5/6), 396-409. doi:10.1108/eb060639

Melewar, T. C., \& Karaosmanoglu, E. (2006). Seven dimensions of corporate identity: A categorisation from the practitioners' perspectives. European Journal of Marketing, 40(7), 846-869. doi:10.1108/03090 560610670025

Nandan, S. (2005). An exploration of the brand identity - brand image linkage: A communications perspective. Journal of Brand Management, 12(4), 264-278. doi:10.1057/palgrave.bm.2540222

Omar, A. J., \& Heywood, C. A. (2014). Defining a corporate real estate management's (CREM) brand. Journal of Corporate Real Estate, 16(1), 60-76. doi:10.1108/JCRE-10-2013-0031

Orozco-Toro, J. A., \& Ferre-Pavia, C. (2019). The effects of branding intangibles on corporate reputation. A complete value chain analysis in the case of Catalonia Television. Revista de Comunicacion, 18(1), 111-134. doi:10.26441/RC18.1-2019-A6

Palm, P. (2016). Measuring customer satisfaction: A study of the Swedish real estate industry. Property Management, 34(4), 316-331. doi:10.1108/PM-08-2015-0041

Price, I., Ellison, I., \& Macdonald, R. (2009). Practical Post-Modernism: FM and Socially Constructed Realities. In Proceedings EFMC 2009 Research Symposium, European Facility Management Conference: 8th Euro FM Research Symposium, June 16-17, Amsterdam.

Punjaisri, K., \& Wilson, A. (2007). The role of internal branding in the delivery of employee brand promise. In J. M. T. Balmer, S. M. Powell, J. Kernstock \& T. O. Brexendorf (Eds.), Advances in Corporate Branding. Journal of Brand Management: Advanced Collections. London: Palgrave Macmillan.

Roper, S., \& Parker, C. (2006). Evolution of branding theory and its relevance to the independent retail sector. The Marketing Review, 6(1), 55-71. doi:10.1362/146934706776861555

Sääksjärvi, M., \& Samiee, S. (2011). Relationships among brand identity, brand image and brand preference: Differences between cyber and extension retail brands over time. Journal of Interactive Marketing, 25(3), 169-177. doi:10.1016/j.intmar.2011.04.002

Sherry, J. (1987). Cereal monogamy: Brand loyalty as secular ritual in consumer culture. In Conferencia presentada en "Annual Conference of Association of Consumer Research”, Boston, Massachusetts.

Skogland, M. A. C., \& Hansen, G. K. (2017). Change your space, change your culture: Exploring spatial change management strategies. Journal of Corporate Real Estate, 19(2), 95-110. doi:10.1108/JCRE07-2016-0024

Stern, B. B. (2006). What does brand mean? Historical-analysis method and construct definition. Journal of the Academy of Marketing Science, 34(2), 216-223. doi:10.1177/0092070305284991

Strati, A. (1999). Organization and Aesthetics. London: Sage publishing.

Themans, S., Koppels, P. W., \& Jylhä, T. (2020). The contribution of the work environment on employee attraction. In The Proceedings of the 19th EuroFM Research Symposium, EFMIC 2020, 3-4 June. www. dropbox.com/s/yp4irmmnanw7fl1/Proceedings_EuroFM_2020.pdf?dl=0

Vallaster, C., \& Lindgreen, A. (2011). Corporate brand strategy formation: Brand actors and the situational context for a business-to-business brand. Industrial Marketing Management, 40(7), 1133-1143. doi:10.1016/j.indmarman.2011.09.008

van der Voordt, T., Brunia, S., \& Appel-Meulenbroek, R. (2016). Satisfaction. In P. A. Jensen \& T. van der Voordt (Eds.), Facilities Management and Corporate Real Estate Management as Value Drivers: How to Manage and Measure Added Value (pp. 67-82). London: Routledge. 